ISSN 1112-9867

\title{
ACTIVATION OF THREADED BOLTING ELEMENTS
}

\author{
P. Dvořák
}

Lihovarská 10/1199, 716 00, Ostrava - Radvanice. The Czech Republic

Published online: 15 February 2017

\begin{abstract}
The article deals with the activation of bolting elements with a thread on them or equipped with threaded bushing through drilling and installation device. The article also enumerates the most frequently used bolting elements of this type and applied equipment with technical parameters in the coal mines of the Ostrava-Karvina coal basin. The essence of the article is primarily to determine the actual height of the induced pre-tension in a bolting element, both in the laboratory and in real mining conditions and to compare these results with used mathematical formulae. The analysis of factors having effect on the level of the induced force and proposals for the limitation and reduction follows. The results show a good agreement of the calculated values with the values actually measured in various conditions. However, the results revealed that the induced input force is low, in the order of tens of kilonewtons. The main significance of the paper is to determine the value of the induced force, influencing factors and proposals to increase this value.
\end{abstract}

Keywords: Anchoring, bolting, drilling device, tensioning force.

\section{INTRODUCTION}

Any bolting element must be activated as soon as possible after installation in order to work properly. Activation or tensioning of bolting elements is important to ensure that all of the components are in contact and that a stabilizing force is applied to the rock. The activation runs by tightening the nut with the drilling and installation device or with a (torque) wrench. The most frequently used types of rockbolts, cablebolts and drilling machines used in the deep coal mines of OKD will be mentioned in following subchapters.

Author Correspondence, e-mail: author@gmail.com

doi: http://dx.doi.org/10.4314/jfas.v8i2s.633 


\section{Steel rebar bolts APB-1k}

As the main means for bolting of underground excavations in OKDmines the steel rebar bolt APB-1k has been used. The bolt is solely installed as a fully resin-grouted rockbolt in connection withLokset polyester resin cartridges. This bolt has been systematically used not only for rockbolting, but also in combination with steel arch support in double-use gates and connecting faces mainly in the lengths of 2,4 and $2,8 \mathrm{~m}$.

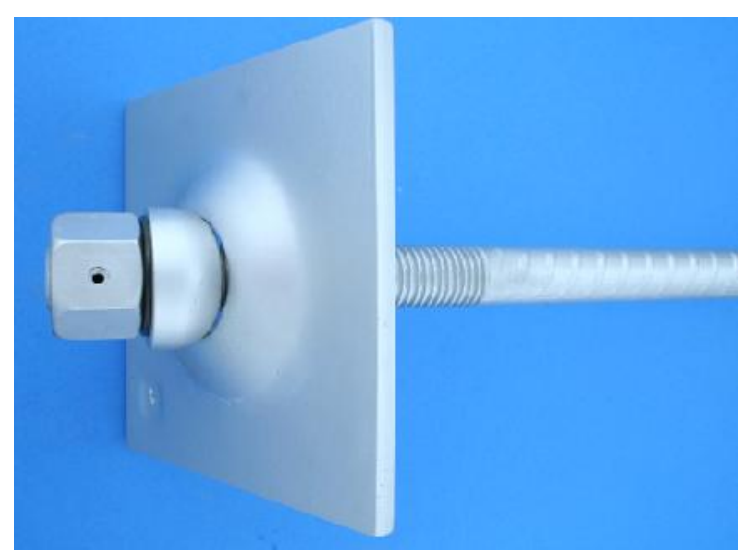

Fig.1. Rockbolt APB-1k with a square washer[1]

Table 1displays technical specifications of APB-1k rockbolt including properties of other bolt modifications made of various steel grades.

Table 1. Technical details of bolts AP[1]

\begin{tabular}{|c|c|c|c|c|c|c|}
\hline $\begin{array}{c}\text { Rebar } \\
\text { bolt }\end{array}$ & $\begin{array}{c}\text { Diameter[ } \\
\mathrm{mm}]\end{array}$ & $\begin{array}{c}\text { Steelgrade } \\
\text { (yield/strength) } \\
\mathrm{MPa}]\end{array}$ & $\begin{array}{c}\text { Load capacity } \\
\text { (yield/strength)[k } \\
\mathrm{N}]\end{array}$ & $\begin{array}{c}\text { Thread } \\
\text { size }\end{array}$ & $\begin{array}{c}\text { Thread } \\
\text { length } \\
{[\mathrm{mm}]}\end{array}$ & $\begin{array}{c}\text { Elongation } \\
\text { A5[\%] }\end{array}$ \\
\hline APB & 21.7 & $640 / 770$ & $235 / 285$ & M 24x3 & 150 & 18 \\
\hline APP & 21.7 & $400 / 600$ & $145 / 220$ & M 24x3 & 150 & 19 \\
\hline APG & 21.7 & $550 / 700$ & $200 / 255$ & M 24x3 & 150 & 20 \\
\hline
\end{tabular}

Rockbolts are typically used with a spherical bearing washer. The convex shape of the washer serves as a load indicator element and as a rockbolt alignment. At a certain value of load flattening of the washer occurs and when the load still increases, than the bolt head pulls through the washer.Table 2 shows the technical details (flattening and pulling through) of the washers. 
Table 2. Technical details of washers[1]

\begin{tabular}{|c|c|c|}
\hline Washer[mm] & Value of flattening $[\mathrm{kN}]$ & Value of pulling through[kN] \\
\hline $8 \times 150 \times 150$ & 180 & 230 \\
\hline $10 \times 150 \times 150$ & 250 & 330 \\
\hline
\end{tabular}

Nuts are fitted with a shear pin at the end of the rod. This allows the introduction of the boltinto the borehole in the first stage and its subsequent activation. Depending on the conditions and the type of insertion machine various types of pins can be used, depending on the size of the required torque for shearing the pin, see Table 3.

Table 3. Torque shearing[1]

\begin{tabular}{|l|l|l|l|}
\hline Shearing pin & Light & Medium & Heavy \\
\hline Torque [N.m] & $40-60$ & $90-120$ & $140-160$ \\
\hline
\end{tabular}

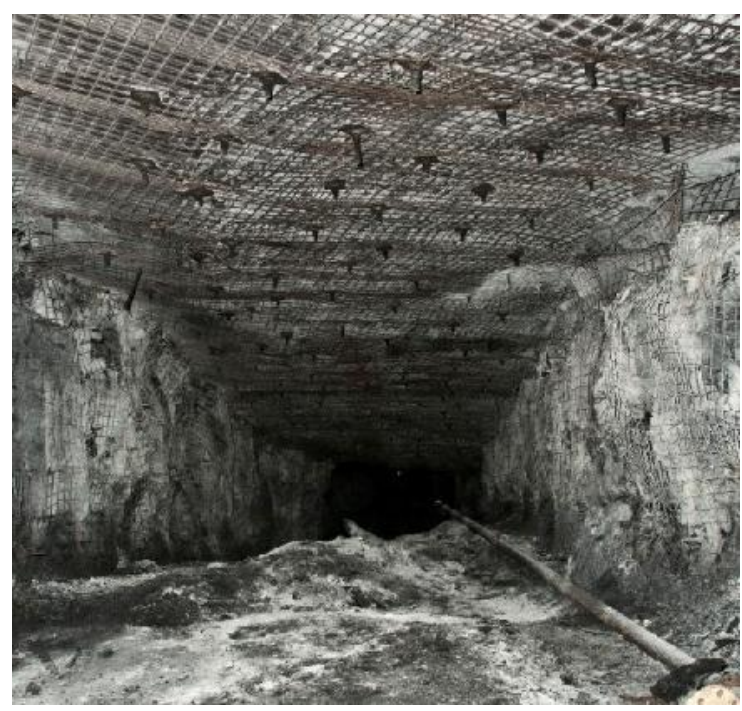

Fig.2. Rockbolts APB-1k, mining plant 2, OKD Inc., photo: Melicher

\section{Strandbolt IR-6/ER}

Strandbolt IR-6/ERis the most common type of long tendon for high bolting in the deep coal mines of OKD in the Czech Republic. The strandbolts are made of spring steel wires with a strength of $1550 \mathrm{MPa}$. The bolthead consists of a steel threaded bushing (see Table 4). The threaded bushing in connection with the internal clamping wedge ensures transmission of tensile loads and serves to activate the strandbolt through tightening the nut after installation. 
The most often used lengths of IR-6/ER strandbolts rangefrom 6 to 13 meters, installed either directly in the rock or more often in connection with a steel joist profile TH29 for reinforcement of steel arch support.

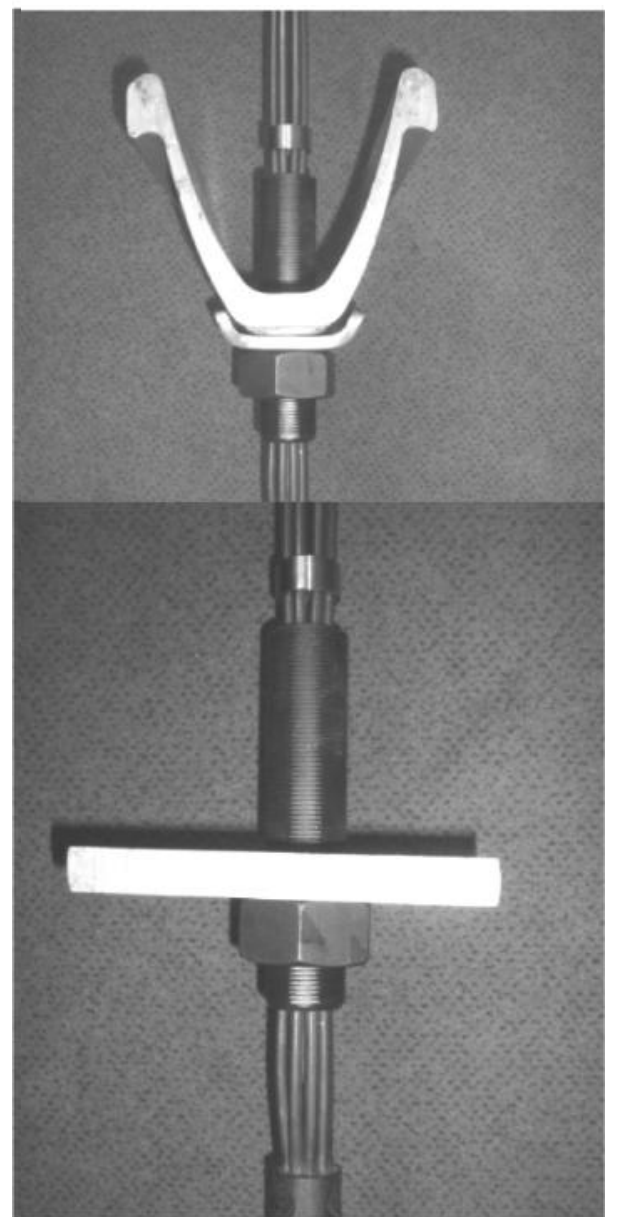

Fig.3. Strandbolt IR-6/ER and its installation variants, Minova Bohemia, Ltd.

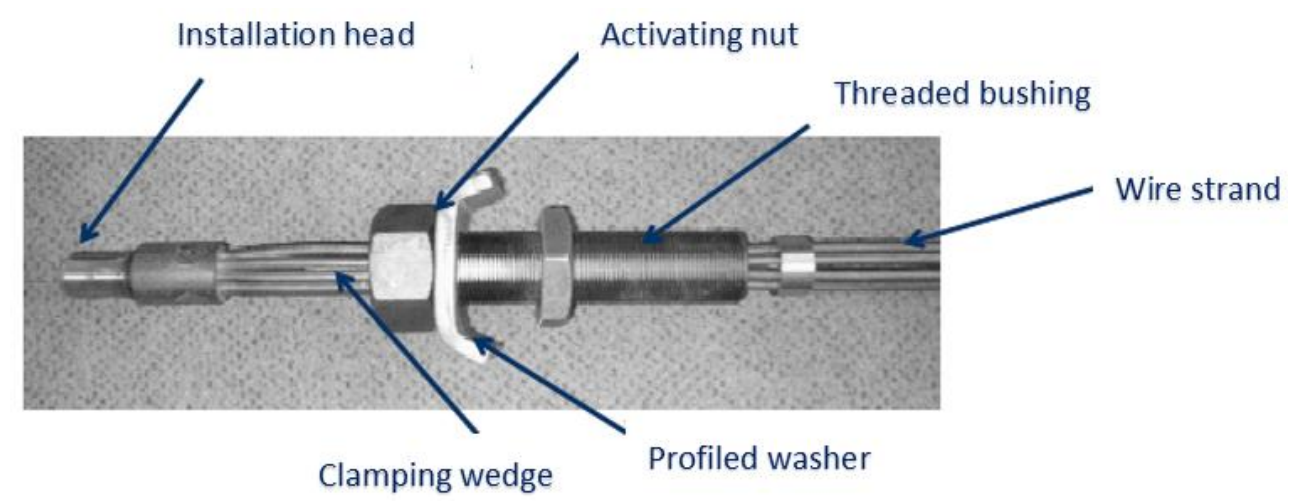

Fig.4. Detailed description of strandbolt IR-6/ER[2] 
Table 4. Technical details of strandbolts IR-6[2]

\begin{tabular}{|c|c|c|c|c|}
\hline \multirow{2}{*}{ Type } & $\begin{array}{c}\text { Load capacity } \\
\text { (yield/strength) }\end{array}$ & Thread size & $\begin{array}{c}\text { Wires/Wire } \\
\text { diameter/Strand area }\end{array}$ & $\begin{array}{c}\text { Strandbolt } \\
\text { diameter }\end{array}$ \\
\cline { 2 - 5 } & $\mathrm{kN}$ & $\mathrm{mm}$ & $\mathrm{pcs} / \mathrm{mm} / \mathrm{mm}^{2}$ & $\mathrm{~mm}$ \\
\hline IR-6/AR & $240 / 280$ & $\mathrm{M} 36 \times 2$ & $7 / 6 / 198$ & 18 \\
\hline IR-6/BR & $270 / 320$ & $\mathrm{M} \mathrm{36x2}$ & $8 / 6 / 226$ & 20 \\
\hline IR-6/BFR & $300 / 350$ & $\mathrm{M} \mathrm{36x2}$ & $8 / 6 / 226$ & 20 \\
\hline IR-6/CR & $325 / 380$ & $\mathrm{M} 39 \times 2$ & $9 / 6 / 254$ & 26 \\
\hline IR-6/ER & $395 / 480$ & $\mathrm{M} 42 \times 2$ & $8 / 7 / 308$ & 26 \\
\hline
\end{tabular}

\section{Drilling machines}

There is an array of machines for drilling boreholes and installing bolting elements (see Table 5). For the purposes of this paper, the author mentions only those machines that are used in OKD mines.

Currently, the compressed air operated, telescopic leg type drilling and bolting machine Super Turbo Bolter (STB) has often been used for drilling and bolting elements installation. It is connected directly to the compressed air in the mine piping. The other most preferred drilling machine is the electrohydraulic pillar drill VS-2.

The STB machine is lightweight, portable and offers a large degree of flexibility in terms of bolt density and operating height. But direct dependence on the pressure in the piping is limiting especially in remote areas where the final pressure in the piping is often less than 1 bar. In such conditions an additional electric drive air compressor is needed (e.g. from Apator). The level of air pressure is essential for the drilling speed, torque leveland the resulting hourly output.

Table 5. Comparison of various drilling machines for bolting (all values are maximal)[3[4, $[5,[6,[7]$

\begin{tabular}{|c|c|c|c|c|c|c|c|}
\hline \multirow[b]{2}{*}{ Machine } & \multirow[b]{2}{*}{ Drive } & Torque & Rounds & Thrust & Weight & \multirow{2}{*}{$\begin{array}{c}\text { Drilli } \\
\text { ng } \\
\text { way }\end{array}$} & \multirow{2}{*}{$\begin{array}{c}\text { Construction } \\
\text { type }\end{array}$} \\
\hline & & [N.m] & {$\left[\min ^{-1}\right]$} & {$[\mathrm{kN}]$} & {$[\mathrm{kg}]$} & & \\
\hline Gopher $^{1)}$ & air & 232 & 650 & 10,3 & 48 & rotary & $\begin{array}{c}\text { hand-operated } \\
\text { telescopic }\end{array}$ \\
\hline STB & air & 350 & 700 & 10,1 & 44 & rotary & hand-operated \\
\hline
\end{tabular}




\begin{tabular}{|c|c|c|c|c|c|c|c|}
\hline & & & & & & & telescopic \\
\hline Rib Bolter & air & 220 & 500 & 10 & 75 & rotary & pillar drill \\
\hline VS-2 & $\begin{array}{c}\text { hydraulic } \\
\text { liquid }\end{array}$ & 300 & 475 & 5 & 70 & rotary & pillar drill \\
\hline $\begin{array}{c}\text { Turmag } \\
\text { FIV }^{2)}\end{array}$ & air & 24 & 1000 & ----- & 7,7 & rotary & hand-operated \\
\hline
\end{tabular}

$\left.{ }^{1}\right)$ predecessor of STB, ${ }^{2)}$ used for drilling in coal pillar (rib bolts, test drilling etc.)

The electro-hydraulic pillar drilling device VS-2 has its advantage in high torque and independence of the locally insufficient air pressure in the piping. That factthus results in higher drilling performance compared to the STB. The advantage is a betterlabourcultureand safety thanks to the remote control panel. The source of energy of this drill is the hydraulic unit. The disadvantages include high weight, difficult handling and high requirements for transportation between sites.
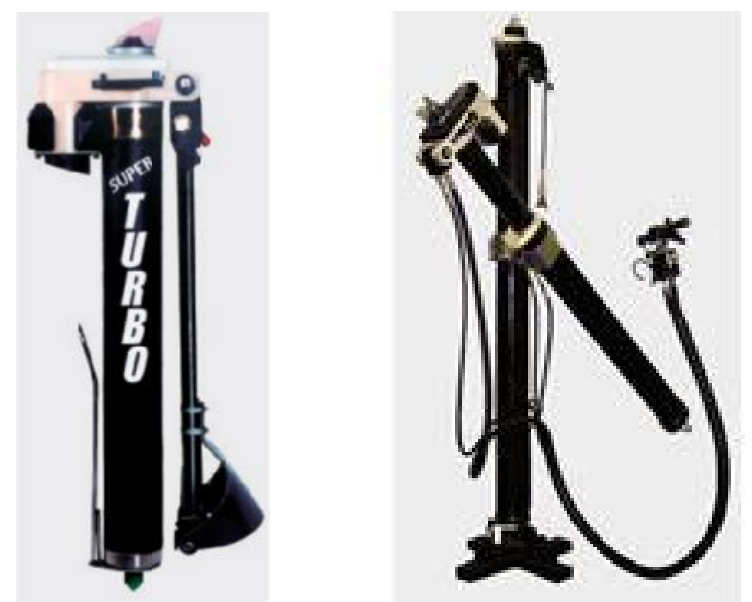

Fig.5. Super Turbo Bolter (left) and Rib Bolter (right), Minova Bohemia, Ltd.

\section{Activation of threaded elements}

Activation of threaded bolting elements is commonly made by the same device as for borehole drilling in the underground conditions. Given the knowledge of the torque of the drillingmachine $\mathrm{M}_{\mathrm{V}}$, the initial induced tension in any threaded bolting or anchoring element can be derived from the equation(1)

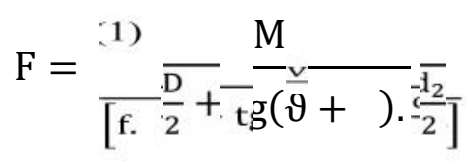


A similar equation is mentioned in[9].

$$
F=\frac{-}{d} \frac{2 \cdot M}{\operatorname{tg} \beta+} \frac{v}{2 \cdot \operatorname{tg} \varphi)}
$$

where $\mathrm{F}$ is the initial tensioning force caused by the torque, $\mathrm{d}_{2}$ mean thread diameter, $\mathrm{D}$ average pitch diameter of the nut/screw, $\beta$ thread pitch angle, $\vartheta$ friction angle in the thread, f, $\varphi$ coefficients of friction on the thread.

Table 6. Technical details of tested threads [1], [2], [10]

\begin{tabular}{|r|c|c|c|}
\hline & & APB-1k & IR-6/ER \\
\hline Thread & & M 24x3 & M42x2 \\
\hline Thread diameter & {$[\mathrm{mm}]$} & 24 & 42 \\
\hline Nut diameter & {$[\mathrm{mm}]$} & 36 & 65 \\
\hline Mean thread diameter & {$[\mathrm{mm}]$} & 22 & 40 \\
\hline Thread pitch & {$[\mathrm{mm}]$} & 3 & 2 \\
\hline Thread pitch angle & $\left.{ }^{\circ}\right]$ & $2^{\circ} 16^{\prime}$ & $0^{\circ} 52^{\prime}$ \\
\hline Average pitch diameter of the & {$[\mathrm{mm}]$} & 30 & 14 \\
\hline nut/screw & {$\left[{ }^{\circ}\right]$} & 14 & 53.5 \\
\hline
\end{tabular}

On the basis of formulae(1)and (2)the initial level of tension can be calculated for conventionally used types of threaded bolts or anchors (seeTable 6)with regards to the particular drilling and inserting machine and its torque (seeTable 7). 
Table 7. resulting tensioning forces in bolting elements induced by a torque

\begin{tabular}{|c|c|c|c|c|c|c|}
\hline $\begin{array}{c}\text { Torque } \\
\text { moment[N. } \\
\text { m] }\end{array}$ & $\begin{array}{r}\text { Resultin } \\
\text { equa }\end{array}$ & $\begin{array}{l}\text { force }[\mathrm{kN} \\
\text { ion }(1)\end{array}$ & $\begin{array}{r}\mathrm{Re} \\
\text { for } \\
\text { equ }\end{array}$ & $\begin{array}{l}\text { ulting } \\
\text { e[kN] } \\
\text { tion (2) }\end{array}$ & $\begin{array}{r}\text { Res } \\
\text { force[kI }\end{array}$ & $\begin{array}{l}\text { lting } \\
(2016)^{*}\end{array}$ \\
\hline & APB-1k & IR-6/ER & APB-1k & IR-6/ER & APB-1k & IR-6/ER \\
\hline 100 & 17.56 & 10.21 & 17.16 & 9.75 & & \\
\hline $150 *$ & 26.34 & 15.31 & 25.74 & 14.63 & $25-33$ & $20-22$ \\
\hline $192 * *$ & 33.71 & 19.60 & 32.95 & 18.73 & $30-34$ & $17-23$ \\
\hline 200 & 35.12 & 20.41 & 34.32 & 19.51 & & \\
\hline 250 & 43.89 & 25.52 & 42.91 & 24.38 & & \\
\hline 300 & 52.67 & 30.62 & 51.49 & 29.26 & & \\
\hline 350 & 61.45 & 35.72 & 60.07 & 34.13 & & \\
\hline
\end{tabular}

*values for APB-1k: 25, 28, $33 \mathrm{kN}$, values for IR-6/ER: 20,20,22 kN

**values for APB-1k: 30, 32, $34 \mathrm{kN}$, values for IR-6/ER: 17,21,23 kN

Test were carried out for verification of these formulae and of their results in practice. For these purposes a hydraulic load cell Glötzl KN 500 A50 and bolting and drilling machine STB 1500/1300 2S with a defined torque 150 and 192 N.m were used.

The experiment was proven on the threaded rods with the thread M42x2 (IR-6/ER) and M24x3 (APB-1k). After installing the measuring system the nut on the thread was tightened by the drilling device to the maximum possible level. Three tests were performed for each type of the thread. The measurement results are shown in Table 7.
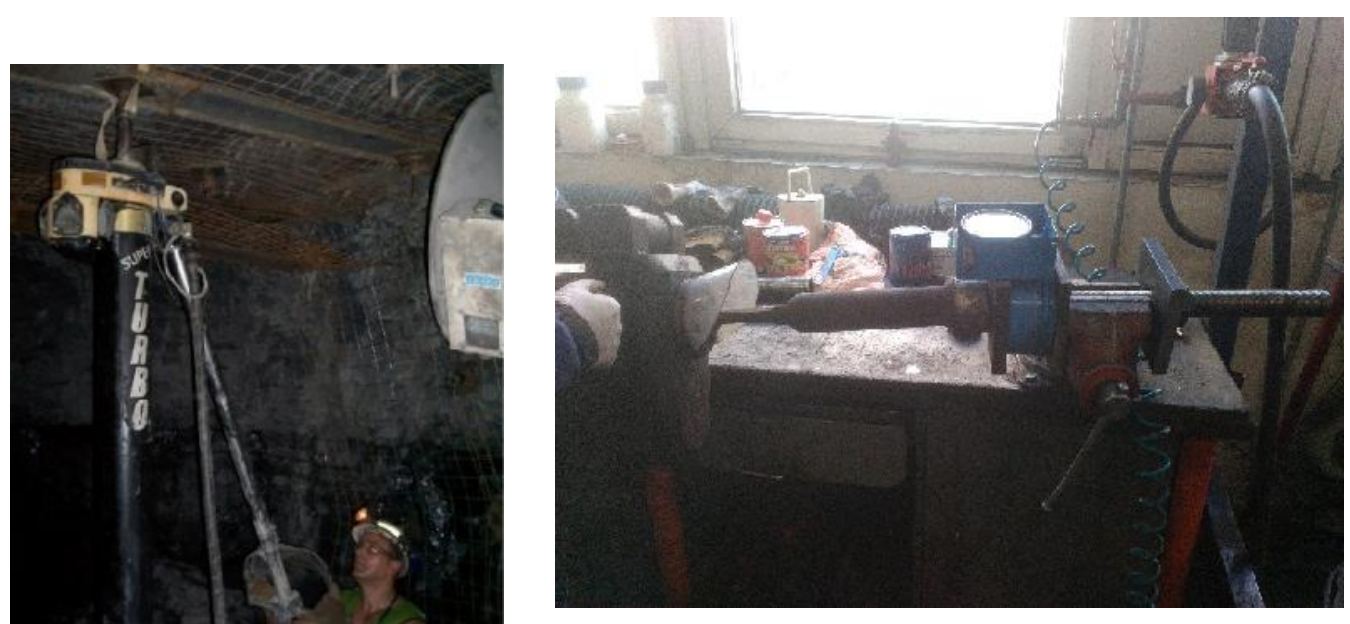

Fig.6. Installation in the mine (left), laboratory test(right), Minova Bohemia, Ltd. 
The biggest influence on the results was the friction between individual elements, friction between the nut, washer and threaded rod. After greasing contact surfaces (the last obtained value of force under Table 7) there was a slight reduction in friction, and thus the resultant increase of the exerted force. It is therefore evident that the magnitude of the induced forces in the element is proportional to the friction in the thread. In mining conditions, it often happens that the threads are heavily fouled up with coal dust or incipient corrosion due to mineralized mine water. This can result in a significant reduction of the initial induced force.

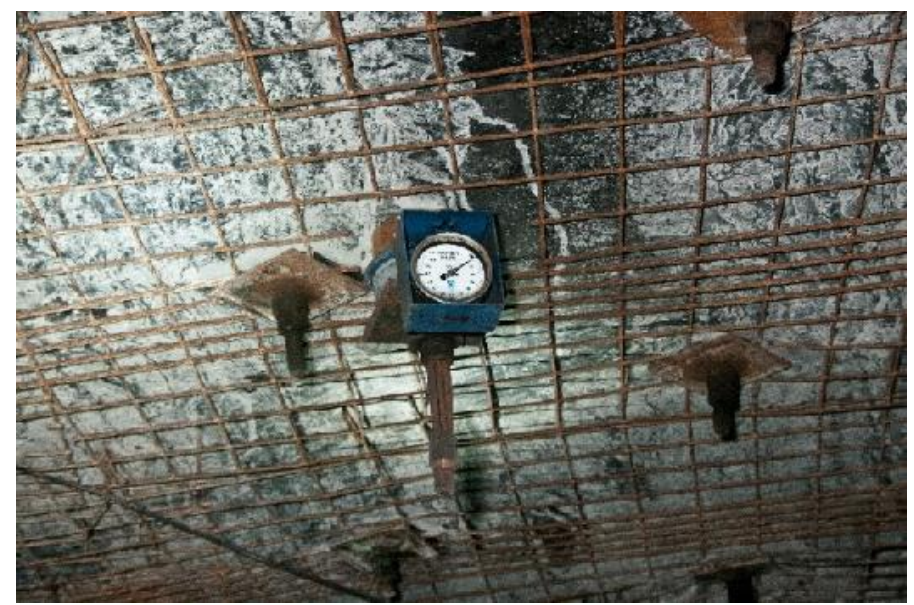

Fig.7. hydraulic load cell (strand bolt IR-6/ER), OKD, Inc., photo: Melicher

The following Table 8 shows the values of initial induced forces in six partially resin-grouted strandbolts IR-6/ER(6m long) with hydraulic load cellGlötzl KN 500 A50. The strandbolts were installed at the mining plant 2, OKD, Inc.in the protective shaft pillar Sever, in the 30th seam where testing operation of the newmining method room and pillar has been ongoing since 2014. This type of strandbolt has been used in difficult geological conditions as a reinforcing support of primary rockbolt support or in galleries with wider span than common $5.3 \mathrm{~m}$ or in junctions. Strandbolts IR-6/ER were installed by standard drilling machine Super Turbo Bolter 1700/1500 2S (see Fig.5) and after installation activated. 
Table 8. Initial induced force in strandbolts IR-6/ER in mining conditions, source: Project RP mining plant 2, OKD Inc.

\begin{tabular}{|c|c|c|}
\hline Strandbolt & Initial force[kN] & Date of installation \\
\hline VD 1 & 30 & 26.11 .2014 \\
\hline VD 2 & 30 & 30.12 .2014 \\
\hline VD 3 & 45 & 5.11 .2014 \\
\hline VD 4 & 25 & 15.1 .2015 \\
\hline VD 5 & 25 & 7.2 .2015 \\
\hline VD 6 & 10 & 17.2 .2015 \\
\hline
\end{tabular}

The values of the initial induced force arein a relatively wide interval. This is due to several factors, changing inlet air pressure (3.5 to 4.5 bar, i.e. lower initial torque), the wear rate of the machine, thread full of coal dust or mud and thread friction between the elements when tightening the nut. After running out the tightening abilities of the drilling machine (or if the air pressure is low in piping) the crew helps itself by twisting the whole machine by operating the control handle. Due to its length (up to $1.5 \mathrm{~m}$ ) a greater torquecan be developed by human power than by the machine itself.

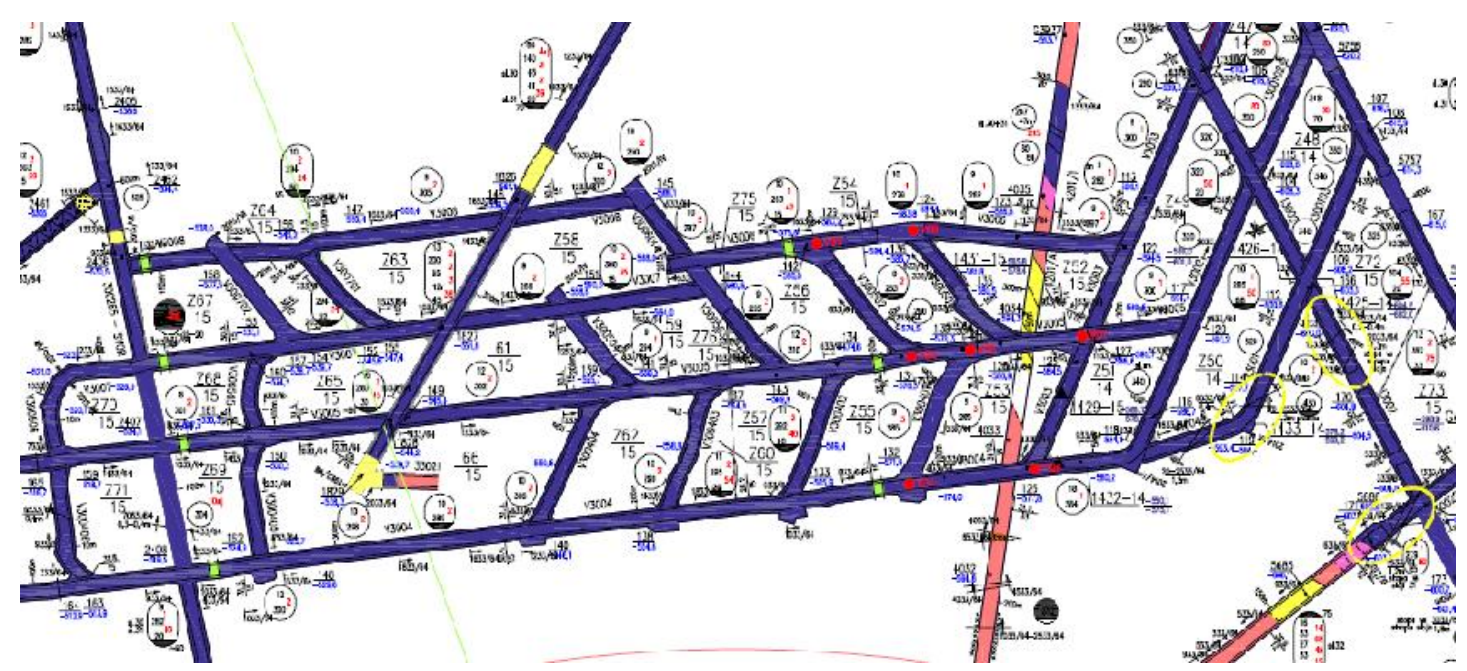

Fig.8. Room and pillar method in mining plant 2, OKD, Inc., red circles - hydraulic load cells VD1-VD6

Bolting elements may also be tensioned by hydraulic cylinders with special adaptors to values equal to several hundreds of kilonewtons, but due to the weight of the cylinders, difficult handling at heights and time intensity of the entire operation, this method has not been used in conditions of OKD mines. 


\section{CONCLUSION}

It is evident that the level of initial force in any threaded element isproportional to applied torque but inevitably limited by the friction between individual elements (nut, washer) and in the thread itself. Commonly used drilling machines do not have a significant torque to induce a higher level of initial force. In that case it is necessary to have a drilling rig, whose torque is higher, or to use a torque amplifier or to use pre-tensionable cable bolts (with barrel and wedges).

Pre-tensionable cablebolts can reach a very high level of pre-tension by a pre-tension jack. The final level is not the same as the initial one. The final value of pre-tension depends on various losses of pre-tension and is time dependent as well.The time-dependent losses affect the threaded elements as well.

\section{LIST OF REFERENCES}

[1] Steel Rockbolts APP, APG, APB.MBo, Ostrava, 2012. [In Czech]

[2]Strandbolts IR-6. MBo, Ostrava, 2014. [In Czech]

[3]Drilling and bolting machine ABS-P Gopher. MBo, Ostrava, 2010.[In Czech]

[4]Drilling and bolting machine Super Turbo Bolter. MBo, Ostrava, 2010. [In Czech]

[5]Drilling and bolting machine Rib Bolter. MBo, Ostrava, 2011.[In Czech]

[6]Drilling and bolting machine VS-2. Koexpro, Ostrava, 2014.[In Czech]

[7]Hand-held drilling machine Turmag FIV a FIV-HT. MBo, Ostrava 2010. [In Czech]

[8]Resin ampoules LOKSET.MBo, Ostrava, 2012. [In Czech]

[9] Hobst, L., Zajíc, J.Anchoring in rock massif. SNTL, Bratislava, 1972.[In Czech]

[10] Drastík, F.et al. Engineering toolbox. Montanex, Ostrava, 2002.[In Czech]

\section{How to cite this article:}

Dvořák P, Activation of threaded bolting elements. J. Fundam. Appl. Sci., 2017, 9(1S), 1-11. 